\title{
ON SOME OBSTACLES AND CHALLENGES TO THE IMPLEMENTATION OF THE CHINESE INITIATIVE ONE BELT, ONE ROAD
}

\author{
Aghavni HARUTYUNYAN \\ Institute of Oriental Studies, National Academy of Sciences of the Republic of Armenia \\ E-mail: aghavni.harutyunyan1@gmail.com
}

\begin{abstract}
In recent years, much has been said and written about the Chinese BRI (Belt and Road initiative): the mainly discussed issues relating to its economic benefits for the participating countries and the possible impact in the global and regional balance of power. However, relatively little attention has been paid paid to the risks and problems affecting the success of the initiative in the long term. The diverse cultural, religious, economic, and socio-political situation in countries along BRI routes contributes to the inevitable and inherent risks and challenges for the project, both domestically and internationally. It may mean that in order to implement BRI, China will have to deal with powerful global competitors and some influential regional powers, which implies a new geopolitical rivalry in Eurasia and the struggle for global influence.

With the expansion of coverage to more than 70 countries, some concerns and complaints have arisen regarding BRI that have received wide publicity. In the expert community and the mass media, mainly in the West, we increasingly see comments on the growing problems of BRI and even forecasts of the possible refusal of developing countries to participate in BRI, due to their unwillingness to become an economic, raw material and financial appendage to the Middle Kingdom. According to critics of the Chinese initiative, previously optimistic participants of BRI will "soon realize" that all promises about the benefits of the project for their economies are greatly exaggerated, therefore they will have to reconsider their financial terms of agreements with the Chinese partners.
\end{abstract}

KEYWORDS: China, OBOR, challenges, risks, criticism, debt-trap, corruption, soft and hard power, security, transparency, environment, responsibility.

\section{Introduction}

This article attempts to explore some of the problems, risks and challenges that China and the countries participating in the New Silk Road (NSR) or BRI have been facing in recent years. The BRI [also called One Belt, One Road (OBOR) or Belt and Road (B\&R)] is the abbreviated name of the double concept of the "Economic Belt of the Silk Road (EBSR/SREB) and the Maritime Silk Road of the 21st Century" (MSR). Launched in 2013 by President of China Xi Jinping, BRI is more than an infrastructure-development plan. As a new model of cooperation, it intends to create "world channels" along the ancient Great Silk Road. President Xi made it clear that China's long term vision was to build the OBOR that covers countries along both the land path and the sea path and by building of these paths NSR project will essentially integrate the entire Eurasian continent (Bai, 2013, p. 12).

Beijing is mulling six economic corridors with countries along the B\&R trade route with funding from the China-led Asian Infrastructure Investment Bank (AIIB) and the Silk Road Fund. Corridors are set to run through:

1. China-Mongolia-Russia Economic Corridor (CMREC);

2. New Eurasian Land Bridge (NELB);

3. China-Central and West Asia Economic Corridor (CCWAEC);

4. China-Indo-China Peninsula Economic Corridor (CICPEC); or China-Southeast Asia Corridors;

5. China-Pakistan Economic Corridor (CPEC);

6. Bangladesh-China-India-Myanmar Economic Corridor (BCIMEC) (Harutyunyan, 2017b, p. 33).

The project aims to connect Asia, Europe and Africa trough three routes of the SREB: Northern - from China through Central Asia (CA) and Russia to Northern Europe; Central - from China through CA to the Middle East (ME) and the Mediterranean Sea; and Southern - from China to Southeast Asia and the Indian Ocean. The MSR involves routes from Chinese ports to the Indian Ocean and further to Europe, as well as to the entire Pacific region (Гостев, 2019).

According to the latest BRI report released by the Beijing, the Chinese government had signed 173 cooperation agreements with 125 countries and 29 international organizations by the end of March 2019 (Dingding, Junyang, 2019). AIIB membership has gone up to 97 countries. Over 1,800 projects of the BRI are underway with over USA $\$ 80$ billion in direct investments in non-financial sectors. China had invested about USA $\$ 30$ billion in over 80 industrial parks abroad. The initial outlays of USA $\$ 800$ billion are yet to be invested - partly due to the reassessments on financial risks (Kondapalli, 2019).

The B\&R project covers an area of 40 million $\mathrm{km}^{2}$ with more than 70 countries included from Europe and Asia, in addition to a $47.100 \mathrm{~km}$ highway, 14 logistics centers, oil and natural gas pipelines, and extensive energy transmission lines. The whole project corresponds to $26 \%$ of the world's surface and 4 billion of the world's population. The BRI is important with these features and a project too big to underestimate. The support for integrated transportation by creating inter-continental roads, maritime and aviation corridors, averting non-tariff 
barriers in trade and paving the way for investment, encouraging intergovernmental cooperation, expanding cultural and human ties, student and staff changes are among the targets. In order to establish this infrastructure, the year 2049 was determined as the target year (Elbir, 2019).

\section{Getting out of the shadows and offering the world its own initiatives}

Since the beginning of the 2000 s, the community of experts has been very optimistic about such concepts as China's "peaceful rise" and its recognition of the role of "responsible participant" in the world affairs (Kaczmarski, 2016, p. 9). In fact, the concept of "peaceful rise," which was replaced by the theory of "peaceful development," was an attempt to counter the theory of "Chinese threat." Thus, China emphasized the peaceful path that it chose to achieve the status of a world power (Арутюнян, 2016, с. 223). Furtherly developing the Chinese strategy of "peaceful development," Beijing began to promote the idea of the "Chinese dream" as a part of the Chinese policy of "soft power," thereby contributing to the formation of a positive image at the international level and opposing the discourse about the "Chinese threat" (Harutyunyan, 2018a, p. 36).

Nevertheless, in recent years, optimism among the expert community and in the media space has to a certain extent been replaced by pessimism and fears about China's self-confidence, its global ambitions and growing ChinaUS rivalry (Kaczmarski, 2016, p. 10). Some experts point to the threat of China's global expansion, believing that China will gradually and steadily increase its political ambitions, defend its position in the international arena, accustom the rest of the world at the beginning of its independent and then leading role (Гузенкова, Карпов, 2013, c. 7). Beijing declared its influence at the global level, in particular, through its BRI project and marked a shift in Chinese foreign policy from Deng Xiaoping's "hide your strength and bide your time" approach to Xi Jinping's belief that it is now China's time to "take center stage in the world" (Cheney, 2019). Thus, Beijing not only showed determination to come out of the shadows safely, but also the ability to offer the world its own initiatives or concepts (Harutyunyan, 2017a, p. 5).

However, the rise of China, its internal problems, the global shift of power from the West to the East, the United States (US) turn in the Asia-Pacific region, China's relations with Southeast Asia due to maritime disputes and Russia's attempt to restore its influence in the post-Soviet space created difficult conditions for China to strengthen its position in the international arena (Szczudlik-Tatar, 2013, p. 1 - 2). And with the struggle of the US, China, Russia and European Union (EU) for global and regional influence, the competition of great powers has become a defining feature of the geopolitical landscape on the world stage (Cheney, 2019).

\section{External geopolitical challenges for BRI}

Despite the fact that the negative economic consequences of unsuccessful reforms, lower oil prices and post-Crimean sanctions partially put Russia in dependence on participation in BRI in order to attract investment in the economy (Trickett, 2017), Moscow fears a large-scale economic and infrastructural expansion of the Chinese initiative (Комраков, 2019). However, at a summit meeting of the Russian President Vladimir Putin and Xi Jinping in May 2015, both leaders signed a joint declaration "on cooperation in coordinating the development of the Eurasian Economic Union (EAEU) and the SREB," thus reaching a new level of partnership and actually creating a "common economic space" in Eurasia (Harutyunyan, 2017c, p. 20; Sputnik, 2015). The biggest outcome of the agreement was the start of the talks on the free trade zone between the EAEU and China, which according to different estimates, might last from 10 to 20 years (Spivak, 2017).

Although OBOR can simultaneously have both a negative and a positive impact on Russia, for Moscow the "intervention" of China in its traditional sphere of influence is undesirable (Trickett, 2017). And this is despite the demonstration of complete mutual understanding on many issues between Moscow and Beijing against the background of growing common hostility towards the US (Bremmer, 2014). Moscow simply cannot fully agree with the role of the bridge and become part of BRI or China's growing presence in the field of logistics, since it has its own integration project - the Eurasian Economic Union (EAEU/EEU). On the other hand, the Russian EEU and the Chinese SREB can to some extent complement each other. BRI can help Russia get more funding and stimulate its market, while Beijing can "count" on Russia's support and partnership amid criticism of the BRI, primarily from the West and India (Gostev, 2019).

There is a view that after changing the geopolitical situation and signing a cooperation agreement between the EAEU and China in 2015, the US and some Western countries changed their intentions to participate in BRI, seeing in it an alternative to EAEU (Иванов, 2018). OBOR is also seen as an economic countermeasure against restoring the US balance in the Asia-Pacific region and insurance against possible unforeseen circumstances in case of danger to its sea routes. Many critics also called BRI as a Chinese version of the Marshall Plan (MP), which aims to achieve geopolitical superiority and even dominance in Eurasia (Harutyunyan, 2017b, p. 205 - 209; China and US Focus, 2015). They argue that OBOR can radically reduce the costs of international trade, as well as support the economic transformations of poor countries (Brautigam, 2019). The US administration of Donald J. Trump in the national security and defense strategies actually openly accused modern China of revisionism and an attempt to destroy the current world order. The subsequent "trade war" between the US and China, and the intensification of 
military activity in the South China Sea have already had a serious destabilizing effect on the security system of East Asia, pushing the region to the very edge of the abyss of the "cold war" (Губин, 2019).

President Trump announced on June 2018 that it would charge a 25\% duty on Chinese imports worth US $\$ 50$ billion, directly named Xi Jinping's industrial program "Made in China 2025" (MIC, aimed at achieving China's dominance in ten key high-tech industries), and repeatedly expressed its concern about China's rising economic, military and global influence (VAAJU.COM, 2018). On May 2019, the US raised tariffs for Chinese goods by USA $\$ 200$ billion from $10 \%$ to $25 \%$, which prompted China to introduce additional tariffs for American goods in the amount of USA $\$ 60$ billion. Then the US began a multi-month process of charging up to $25 \%$ of tariffs from almost the rest of China's exports to America, estimated at about USA $\$ 300$ billion (Bermingham, 2019). The lack of transparency regarding OBOR has become not only one of the main sources of US objections to the implementation of the BRI, but also in wider current "trade war" and economic disputes between the US and China over justice and reciprocity for US companies operating in China (Feng, Gabuev, Haenle, Bin \&Trenin, 2019).

MIC also dispelled European former hopes for political and economic liberalization in EU (Легран, 2019). Despite the growing exchanges and the expansion of cooperation between the EU and China, there are some problems associated with the growing protectionism in the EU since 2016, which has led to increased anti-dumping and anti-subsidy investigations regarding Chinese goods (Xinhua.english.news.cn, 2017). EU protectionist measures cause frequent disagreements on issues related to public procurement in China, and recognition of the market status of Chinese state-owned enterprises (SoE) (Zhang, 2015).

Moreover, EU strategy on "Connecting Europe with Asia," released in September 2018, seems to set out very different principles to those of China's BRI (Chan, 2018), and can be seen as an important first step in countering China's integration towards the West (Bart, 2018). In relations with China, the EU faces problems such as Chinese exports of its own development model to target countries, the rapidly growing trade gap between the EU and China (Chan, 2018), labor rights, equal conditions for business, environmental and economic sustainability of various Chinese projects (Cameron, 2018), large-scale Chinese investments (the purchase of European companies and technologies), a reduction in European direct foreign investment in China, etc. (Chan, 2018). However, market access in China to [foreign direct investment] from the EU is still highly restricted. There is a common complaint about opaque connections between Beijing and Chinese enterprises, and the lack of reciprocal market access in China. Beijing has repeatedly expressed its commitment to further open its domestic market to foreign competition and has shown signs of offering concessions (Harutyunyan, 2018c, p. 7).

Nevertheless, against the background of the growing geopolitical competition, China is working on its global rise, while paying special attention to domestic development and maintaining political and social order. Despite insufficient experience in many regions and not battle-tested, China's global presence and influence is expanding, Beijing's weight in the international system is growing steadily, gradually "displacing" the US from its leading position and using relations with Russia to ensure a stable geopolitical rear and flow of energy, militarytechnological and other resources (Trenin, 2019).

\section{Security implications for BRI}

Since the B\&R is not only an economic, but also a geopolitical initiative, the growth of China's economy and its impact on the NSR adds a security component to this initiative, remaining a decisive problem in the success of the BRI. Thus, with the growth of China's geopolitical weight in the world, the security burden that it will have to bear will increase. Maritime piracy, human trafficking, smuggling of drugs along the NSR route, terrorist actions by militant groups such as the ETIM (East Turkestan Islamic Movement), Pakistani and Afghan Taliban, al Qaeda, the Islamic State, and other militant groups, extremely threaten the implementation of Chinese projects, people working on them, and diplomatic missions.

The long-term BRI planning can be hampered by the internal political instability of the target investment countries, where in case of a change of government, civil wars and armed conflicts, the new leadership may terminate the agreements concluded with China (Maráczi, 2017). Beijing is concerned about a possible "domino effect," as a result of which political instability in neighboring states may spread to its northwestern provinces of China, especially to the Xinjiang Uighur Autonomous Region (XUAR) (Brugier, 2014, p. 3). Xinjiang's remoteness and terrain, as well as persistent security concerns about the region's restive Uighur Muslim population, will constrain Beijing's most ambitious visions of trans-Eurasian road, rail and pipeline systems (Bujak, Śliwa, 2016, p. 445).

One of the most important and dangerous on the BRI is the CPEC, which crosses the border between India and Pakistan in the disputed territories of Kashmir - Baluchistan province, with deeply divided ethnic communities and separatist groups, and where the most important for BRI port of Gwadar is located (National University of Singapore, 2017). In addition to separatist movement by ethnic Balochs, the province's capital city of Quetta continues to be a "safe haven" for Afghan Taliban leadership (Dubow, 2017). In 2019, the Majeed Brigade of Balochistan Liberation Army's (BLA) reportedly urged China and Pakistan to withdraw their projects from Balochistan province in Pakistan or, in case of refusal, to face retaliatory actions (Sputnik, 2019). 
Perhaps the most important issue for the SREB is the influence of ISIL (Islamic State in Syria and Iraq) the foreign and multinational force that pursues transregional and even international terrorist goals, acting in Afghanistan and CA (Pars Today, 2019). China's security focus on Afghanistan and CA is intended to counter Uyghur militants who have moved to the region after the defeats suffered by the ISIL and the group's establishment of a base in Afghanistan and the Pakistani province of Baluchistan. It also aims, together with efforts to break off contacts between the Uyghurs and their brethren from CA, restrain the influence of the non-violent groups of the Uighur diaspora living in CA for decades (Dorsey, 2018). China announced as well the arrival of hundreds of Chinese militants in Syria and Iraq, mainly Uighurs and a small number of Hui Muslims. Unlike Al-Qaeda, which is quite cautious and tactful in its statements towards China, the Islamic State (IS) included on its list the problem of East Turkestan, and its leader Abu Bakr Al Baghdadi directly "mentioned" China in his speeches (Domínguez, Juan, 2015).

Although Pakistan's armed forces promised to provide a detachment of 10,000 to protect the Chinese working on the CPEC project (Maráczi, 2017), it has been suggested that the Pakistani government's ability to protect the CPEC looks dubious, given its tendency to distinguish between "good" and "bad" jihadists (Dubin, 2017). Moreover, the withdrawal of the US and the International Security Assistance Force (ISAF) from Afghanistan can raise serious questions about ensuring security of BRI projects in CA and beyond (Institute for Security \& Development Policy, 2016, p. 5).

Beijing should also create a more stable and peaceful environment in African countries where security risks are present. This is evidenced by the recent abductions of Chinese expatriates in Nigeria, the killing of several Chinese builders and doctors between 2012 and 2014 in the northeastern states of Nigeria, and the states of Borno, Boko Haram strongholds, the destruction of Chinese workers in factories in Lagos, and escape after a series of abductions of Chinese expatriates from the construction site for the road connecting the cities of Lokoja and Benin in April 2018 (Pars Today, 2019). Actually, as China increases its exposure in Africa and starts to acquire assets, its views on the stability of partners and their ability to provide security for its interests increase (Brown, 2018, p. 219).

Transnational organized crime, such as drug smuggling, illegal immigrant crime and transnational economic crime, are becoming more common and have a serious impact on the economic development and social stability of all countries involved in B\&R (Liu, 2017, p. 140-141). Since many of the BRI transport projects (for example Myanmar) ${ }^{1}$ overlap existing routes of trafficking and smuggling, the reconstruction of old highways and the construction of new roads may facilitate the smuggling of drugs and expose formerly isolated areas to illicit trafficking (Dubow, 2017).

\section{Transforming China's soft power through BRI into hard power}

With BRI as a comprehensive "ecosystem" and with hard and soft power, China essentially integrates the global economy to support vital economic corridors and infrastructures. There is a view that the BRI member countries are increasingly worried that the advancement of China's soft power through B\&R may soon become a hard power (Feng, Gabuev, Hanley, Bin, Trenin, 2002). Southeast Asian countries, despite China's claims of respect for their sovereignty, fear from China's growing power, infringement of their freedom of navigation, investment from Chinese companies that want to enter strategically sensitive areas like ports, communications or energy infrastructures (Maráczi, 2017). Without serious obstacles, China fully or partially buys critical infrastructure in Europe - ports in Belgium, the Netherlands, Spain, Italy and, in particular, Greece and so on (Cameron, 2018).

It turns out that even if Chinese diplomatic principles reject the "spheres of influence" mentality, "they are not against" temporary military deployment, if Chinese interests (in this case, BRI projects) are under threat (Degang, 2015). But the fact is that the Chinese MSR with its two megaprojects CPEC and BCIM-EC is connected with the existing "String of pearls"2 - China's network of maritime facilities in the Pacific and Indian oceans. This can fundamentally change the political and economic situation in the Indian Ocean, but can also solve security problems along the MSR, from territorial disputes in the South China Sea to transnational threats, such as piracy, armed robbery and terrorism (Harutyunyan, 2017b, p. 95-96).

So, China explains the creation and rational use of its military bases (or maintenance points in Djibouti, Oman, Saudi Arabia, Sudan) to combat piracy on the west coast of the Indian Ocean and to ensure energy security in the Persian Gulf region (Liu, 2017, p. 144). Piracy is especially a threat in the Gulf of Aden which is one of the busiest waters in the world and where at least 20,000 ships carry 12\% of the world's oil every year (Liu, 2017, p. 134). In order to launch joint anti-piracy exercises and to lay the foundation for further military cooperation in the Western Indian Ocean and the Persian Gulf, the Chinese conducted military exchanges between Thailand, Myanmar, Cambodia, Pakistan, the Maldives, Sudan, Seychelles, Saudi Arabia and other countries (Degang, 2015).

\footnotetext{
${ }^{1}$ Myanmar is already at the top of the Golden Triangle (the main opium production region in Southeast Asia). According to the UN Office on Drugs and Crime (UNODC), two-thirds of China's opioids come directly from Myanmar.

${ }^{2}$ String of Pearls strategy - this approach centers on establishing Chinese footholds with military or geopolitical influence along the Indian Ocean littoral and into the Persian Gulf and Mediterranean.
} 
This undoubtedly causes concern to the West, India and other countries of the region about China's growing influence in the Indian Ocean, fearing that Chinese-supported civilian and port facilities in Sri Lanka and other places will be regularly used for China's naval forces as a hub in Beijing's alleged "String of Pearls" strategy. Partly to ease India's fears, the Sri Lankan government banned Chinese submarines from visiting ports in early 2015 (Panda, 2015).

\section{China's engagement in debt-trap diplomacy through the BRI}

The Western press constantly focused on "debt traps," "yellow peril" and "Chinese colonialism" narratives, often taking as an example the Chinese presence in Africa, and connecting with the long-time phobia of the "yellow peril" (Tritto, Camba, 2019). It is said that OBOR is a powerful game of China on a geopolitical chessboard, claiming that "strategic motives" stand behind it (Harutyunyan, 2018d, p. 52). B\&R's critics view the initiative as a geopolitical ploy by Chinese President Xi Jinping to lure developing countries into a debt trap and thus become indebted to Beijing (Molavi, 2018). Distrust of China is a serious problem in many countries, some of which view BRI as a claim of China for the role of world superpower, some are afraid to rely too much on trade with China and Chinese investment. Even for those who are not inclined to see BRI as a "Trojan horse" for Chinese influence or nineteenth-century reincarnation of imperialism, this gap in stability is the main cause for concern regarding $B \& R$ projects (Feng, Gabuev, Haenle, Bin, Trenin, 2002).

According to some critics, the gradual establishment of control over significant assets for China, primarily natural resources, with increased political influence over the countries will occur not so much through open participation in political processes, but rather through the establishment of control over property (Harutyunyan, 2016, p. 37). Thus, BRI is mainly seen as an attempt to ensure a stable supply of raw materials, mainly from Asia, Africa and the ME, and to link the economic fates of its Asian neighbors with China (The Hague Centre for Strategic Studies, 2018).

Some analysts, especially in Africa, argue that many China-funded projects are not particularly beneficial for local people, and are merely a way for China to access a country's market and resources. They complain that conditions on Chinese loans and investments become very clear only when recipient countries face a debt crisis. Since Beijing usually spent more money in corrupt countries, with a negative correlation between Chinese government direct investment and the World Bank Rule of Law index, Chinese investment is sometimes associated with "extreme exploitation, extreme corruption and political interference" (Deutsche Welle, 2018).

Chinese investors are accused of becoming pickier in promoting their interests and financing their projects, not intending to distribute cheap cash to other countries (Spivak, 2017). In recipient countries of Chinese aid or investment, especially among neighbors who have previously made a deal with Beijing, there is some caution about loans with high interest rates, low security standards (Huong, 2019), revaluation of projects, lack of transparency and high levels of corruption, accompanied by nepotism and kickback, defaults with economic and political consequences (Almeida, 2018).

The vast majority BRI financing takes the form of loans at market rates, estimated in mid-2018 to be around US $\$ 400$ billion. A review of a sample of BRI projects found 40 cases of debt renegotiations, involving 24 countries, totaling more than US $\$ 50$ billion. This usually took the form of China unilaterally cancelling debt or deferring repayment. Examples include writing off loans of USA \$90 million to Cambodia (2016) and US \$2.2 billion to Mongolia (2017). So, the Sri Lanka debt-trap case is therefore an exception, not the rule (Abonyi, 2019).

However, it should be noted that Chinese money is especially attractive to many developing countries, because it does not come with the human rights conditions, good governance requirements, approved-project restrictions, and environmental quality regulations that are tied to money from Western governments (Harutyunyan, 2018 b, p. 184). In exchange, at least at this stage, Beijing expects to gain mainly loyalty to itself, to Chinese ideas and values (Гостев, 2019).

\section{Some countries that are already trapped in debt}

Indeed, a large-scale BRI infrastructure project is quite expensive and some developing countries, receiving a loan in proportion to their participation, find themselves in a debt trap that threatened their economy and stability (Mokhtari, 2018). Some of China's foreign partners (Venezuela, Sri Lanka, Cambodia, Myanmar, Pakistan, Malaysia, Maldives) are already in a debt trap and are facing problems in repaying them (Hornby, 2018).

The debt-trap argument gained further credence after Malaysian Prime Minister Mahathir Mohamed, upon taking office in May 2018, canceled USA \$23 billion in BRI projects, including a USA \$20 billion railway, citing high costs (Hornby, 2018; Pei, 2019) and charging China with "implementing a new version of colonialism" and spoke of the BRI as an example of China's 'unequal treaties'(Akpaninyie, 2019).

Sri Lanka found itself in a Chinese debt trap having difficulty repaying a loan. China's construction in Port City Colombo, an artificial island worth USA \$1.4 billion, was suspended after the election in 2015 of the President of Sri Lanka, Maithripala Sirisena, who accused his predecessor of having offered too many concessions to China (Vien, 2015). China also acquired 99 years of operating rights to the port of Hambantota in the south of Sri Lanka 
after the project costs went out of control, forcing Colombo to relinquish control of the port in exchange for China's help (Hornby, 2018). 70\% of the port was sold to a Chinese company. But the Hambantota loans accounted for only a tiny share of Sri Lanka's debt overall. When the sale of the port was negotiated in 2016, Sri Lanka had an external debt of USA $\$ 46.5$ billion. According to International Monetary Fund (IMF), only $10 \%$ of it was owed to China and "Sri Lanka's debt problem isn't made in China" (Brautigam, 2019). As a result, the port and surrounding acres of land, strategically located at the crossroads of the Indian Ocean, the Bay of Bengal and the Arabian Sea, will now be under Chinese control until the year 2116 (Cameron, 2018).

In October, 2018, Pakistan's new government has called for a review of the CPEC, to which China has committed more than USA $\$ 60$ billion in funding (Pei, 2019). There is a risk that the amount of Chinese investment can easily cause hostile emotions among local residents. Some poorer provinces, such as Baluchistan and Khyber Pakhtunkhava, accuse the Punjab-dominated government of expropriating the benefits of developing the Punjab center. Other provinces prefer to stay away from Chinese investments because they see them as a threat to their traditional way of life (Maráczi, 2017).

In February 2015, the Government of Cambodia (one of the most dependent countries on China in terms of investments and grants) announced that the approval of the Sinohydro dam construction project in the country worth USA $\$ 400$ million was suspended until at least 2018. Dam has been criticized by non-governmental organizations for environmental reasons (The Economist Intelligence Unit Limited, 2015, p. 8). The country has already begun to talk about a more demanding attitude towards Chinese investors due to the strong socio-economic and environmental changes in the port city of Sihanoukville (Молдашев, 2019, с. 5).

In 2011, just two years after the start of a USA $\$ 3.6$ billion project, the Myanmar government suddenly suspended construction of the Chinese company China Power Investment (Chellaney, 2016), which was faced with attempts to develop the Myitsone hydropower plant in Myanmar with an installed capacity of 6,000 megawatts (MW) (The Economist Intelligence Unit Limited, 2015, p. 8). The initial transaction (according to which $90 \%$ of the electricity produced was to be sold to China, and the rest was given to Myanmar free) was strongly criticized in Myanmar and was considered a "one-way" deal in favor of China, with only a few advantages for Myanmar. There were also concerns that China's control over one of Myanmar's "main sources of water" would make the country "more vulnerable" to pressure from Beijing (Ramachandran, 2019). After work on the Myitsone Dam halted, several other dam and energy projects were also put on hold, though Chinese firms did manage to complete multibilliondollar oil and gas pipelines from Myanmar's western coast to southern China in 2013-2014 (Chellaney, 2016).

The Maldives, the tiny island nation in the Indian Ocean, is trying to renegotiate down the USA $\$ 3$ billion debt (equal to two thirds of its gross domestic product) it has borrowed from China to fund BRI projects (Pei, 2019). There is a view that India is considering giving the Maldives interest-free loans of up to USA \$1 billion to help them pay off their debt to China, but only if the Maldives agrees to distance itself from Beijing, and in exchange for strengthening security ties, including the permanent deployment of Indian military personnel in the island country (Kuronuma, 2018).

About 17 low-income African countries have either been faced with a "debt crisis," or have had difficulty servicing their public debt. There are reports of more than 1,000 Chinese loans in Africa between 2000 and 2017, totaling more than USA $\$ 143$ billion (Brautigam, 2019). Ethiopia has also experienced debt concerns over Chinesebuilt projects. Repayment on its USA $\$ 4$ billion railway linking capital Addis Ababa with neighboring Djibouti has been extended by 20 years over concerns of debt distress. Concerns about China's unsustainable lending in Zambia have forced critics to say that China will take control of key government assets because of Zambia's debt (Akpaninyie, 2019). There is a view that China may as well seize the port of Kenya Mombasa, unable to pay USA \$2.27 billion in debt (Kondapalli, 2019).

In Latin America and the Caribbean, aside from "the important possible exception of Venezuela," financing from China alone did not appear to be driving borrowers above the IMF's debt-sustainability thresholds. Boston University's Global Development Policy Center has identified and tracked more than USA \$140 billion in Chinese loans to Latin America and the Caribbean since 2005 (Brautigam, 2019). Chinese investment alone in Latin America is USA $\$ 88$ billion (Гостев, 2019).

It is remarkable that many of the $\mathrm{B} \& \mathrm{R}$ countries are already among the most corrupt in the world. Transparency International's Corruption Perceptions Index ranks Uzbekistan, Tajikistan, Kazakhstan, Turkmenistan, Afghanistan and Kyrgyzstan as highly corrupt countries, while Russia, Pakistan, India and Mongolia received only slightly less dismal ratings, which leads to skeptical predictions about the possibility of proper absorption of capital from B\&R projects in the local economies (Institute for Security \& Development Policy, 2016, p. 5). According to the Information Analytic Center (IATS MGU) (2019), the German-American team of economists came to the conclusion that the list of the 50 largest recipients of direct Chinese loans made by them included important allies and partners of Russia: Belarus, Kyrgyzstan, Tajikistan, Turkmenistan, and Uzbekistan. Kyrgyzstan owed China 30\% of its GDP. Thus, Kyrgyzstan was in the top five most indebted countries along with Djibouti, Tonga, the Maldives and the Republic of Congo. The volume of its debt to China reached 30\% of Kyrgyz GDP. Belarus has debt to Beijing at 13\% of GDP. Both countries are Russia's partners in the EAEU, as well as the allies of the Russian Federation in the Collective Security Treaty Organization (CSTO). This military-political alliance with Russia also includes Tajikistan, which owes China about 15\% of its GDP. In Turkmenistan, the share of debt, 
presumably, is somewhat higher than that of Belarus, for Uzbekistan, for which Moscow now highly expects economic and political rapprochement, it exceeds 5\%. At the same time, the share of the Russia's partners in the EAEU and the CSTO of Armenia and Kazakhstan is less than 5\% (ИАЦ МГУ, 2019).

\section{Problems concerning free trade, customs procedures, corruption, transparency, restriction of direct investments with $B \& R$ countries}

There are also problems with political barriers and impenetrable borders of some of the states on the BRI. Transit delays, customs procedures and restrictions, limitation of direct investment in these countries require political reform and cooperation among countries. Economic indicators demonstrate that it takes 50 days to pass through a country in CA, while this time in the Group of Seven (G7) countries is around 10 days (Mokhtari, 2018). In addition, if SREB land transport routes in Eurasia help save on delivery time, sea logistic support is still at least $50 \%$ cheaper. Currently, the trade flow from China to Europe on land routes is almost one way, which is not economically efficient (Spivak, 2017).

In the maritime sector, the promotion of the Chinese project requires the signing of numerous agreements between Beijing and the Association of Southeast Asian Nations (ASEAN), as well as the EU. On the other hand, there are a number of countries that are on the fixed line of the Chinese NSR, and barriers to free trade are still not eliminated in customs agreements (Pars Today, 2019).

We meet as well a lot of negative statements in the world community that the goal of the B\&R project is to transfer China's excess production capacity to other countries, such as steel, cement, etc., while stimulating its stateowned enterprises (Molavi, 2018). Besides, in order to provide control over its investment infrastructure projects (roads, transport), China requires that the management company, technology and labor be Chinese (Алиев, 2019). The initiative would also promote the renminbi (RMB) as an international currency, primarily at the expense of the US dollar (Abonyi, 2019). In addition, there is a view that Chinese leaders openly criticize protectionism and call for principles of the free market, but are themselves accused of categorically denying an open society within China (Хубиев, 2019).

According to some experts, there is no clear legislation establishing responsibility for corruption, when investments outside the country put the Chinese investor in the preferred position in the short term. However, if an investor can avoid the expensive costs required to fully comply with local laws and "negotiating," then in the medium and long term, this strategy carries risks for Chinese investors, including within the framework of BRI. Firstly, because there is a risk of becoming an object of discontent from the societies of recipient countries; and secondly, with the possible change of the old regime, the new authorities, even with the support of relations with China, may not share the enthusiasm of their predecessors (Молдашев, 2019). As a result, short-term interests that have damaged China's image can harm its long-term economic interests.

One view, expressed by Dingding \& Junyang (2019) is that to improve transparency, each country is supposed to provide more comprehensive and detailed information on budget documents, such as the project basis, implementation proposal, fund allocation, and performance appraisal. The mechanism of an open legislative hearing could be established to allow the public to testify and get involved in the review. Plus, the whole process of publicly reporting the preliminary preparation, mid-term inspection, and evaluation of the government budget should become a regulatory norm. If this can be realized, all these aforementioned criticisms on transparency will wind up collapsing on themselves (Dingding, Junyang, 2019).

\section{The need for a good study of the Chinese experience of financing BRI projects}

Beijing argues that BRI projects supported by various financial mechanisms of Chinese banks, the Big Four and state-owned enterprises will benefit the local population and are intended for joint development (Tritto, Camba, 2019). According to Brautigam (2019), even if debts are growing in developing countries, there is little evidence that Chinese banks act on behalf of their government, deliberately overestimating or financing unprofitable projects to provide China with a strategic advantage (Brautigam, 2019).

China's state-owned banks, including the China Development Bank and the Export-Import Bank of China, finance more than $70 \%$ of BRI's projects, depleting China's foreign exchange reserves. State-owned enterprises (SOEs), such as COSCO Shipping Ports, play a leading role in implementation, performing $95 \%$ of the work. But private sector participation was minimal and declined, reaching only $4 \%$ of BRI loans in 2018. China's banks, in taking on debt to finance underperforming BRI investments by SOEs add to the growing non-performing domestic loans already on their balance sheets. In implementing BRI projects, the SOEs behave as they do domestically, maximizing investment and output, not return-on-investment or profit. This distorts pricing of investment risks, pushing up the borrowing costs of generally more efficient private firms. In 2018, rising SOE debt levels reached RMB100 trillion, or $120 \%$ of GDP. SOE return-on-assets (ROA) averaged $3.9 \%$, compared with $9.9 \%$ for private companies (Abonyi, 2019).

One view, expressed by Akpaninyie (2019) is that instead of a state-run strategy, Chinese firms motivated by profits and bureaucratic disorganization, incompetence and negligence at the state level, exploit poor countries 
that depend on cheap or bad loans. These companies, consciously or unconsciously, convince countries to undertake projects in which the benefits to firms far exceed those of the host country. Even worse, host governments are signing non-concessional loans with high interest rates or onerous conditions that put disadvantaged countries at a disadvantage (Akpaninyie, 2019).

Worth to note, that most Chinese banks are comparatively less experienced in cross-border and international transactions, or transactions on a very large scale, and are still very focused on domestic lending. They may not be fully aware of typical project financing models or transnational risks. It is necessary before making any investment decision and prior to agreeing on contracts to determine the risks and work out ways to eliminate them (Huw, 2017, p. 4).

Huw (2017) emphasizes the need to a good study of the Chinese experience of project finance, which is quite different from that in the West. China has laws that restrict guarantees that can be given by state entities so the concept of Public-Private Partnerships just doesn't work in China. You cannot guarantee debt in the same way from a state organization. China takes a more commercial rather than government liability perspective, shifting the risk much more to the private sector (Huw, 2017, p. 5).

\section{Environmental degradation and the loss of bioavailability}

The potential risk of environmental degradation and loss of bioavailability is another challenge for the implementation of BRI. Governments in underdeveloped and developing countries often reduce environmental standards to attract foreign investors, despite the fact that infrastructure projects (railways, roads, pipelines and power lines) usually carry risks of reducing changes in ecosystem biodiversity and pollution during construction and operation. But with the development of the economy and the deterioration of the ecological situation, the growth of requirements for foreign investments and for their own governments in terms of environmental safety is inevitable (Молдашев, 2019, с. 4 - 5).

For many Chinese firms, labour relations, environmental protection and CSR (Certificate Signing Request) are new challenges, especially in countries where political opposition and environmental and social activism is robust. Foreign governments are increasingly requiring comprehensive environmental and social impact assessments and compliance with stringent environmental and workplace laws. Governments may not be willing, or have the ability, to intervene if standards are not met or disputes arise, forcing Chinese contractors into the highrisk situation of having to negotiate directly with labour unions or local communities. Project delays can result in cost overruns and also make it harder for a contractor to win future projects in that country (Wong, Jia, 2017, p. 24).

However, an alternative view is that not only Chinese companies are responsible for the damage caused to wildlife and environmental degradation, but also corrupt and incompetent local authorities in many countries that don't hesitate to transfer their natural resources, national parks, etc., to the Chinese or any other country (Gostev, 2019). A similar view is held by Mokhtari (2018) who suggests that before carrying out any infrastructure projects and transportation, it is necessary to identify and carefully eliminate environmental hazards in order to minimize damage to the environment and habitat (Mokhtari, 2018).

In this respect, remarkable that during the Chinese B\&R Forum 2019 in Beijing, President Xi Jinping promised to make the environment the central task of any BRI infrastructure projects and build only "high-quality" infrastructure (Sharma, 2019). Xi declared that the BRI would make the world a more beautiful place with initiatives such as the Sustainable Cities Alliance and International Green Development Coalition, green investment principles for BRI projects, and a commitment to sustainable development (Huong, 2019).

\section{Some allegations about non-coercive nature of the BRI}

Beijing has repeatedly confirmed that the BRI, as a dream of development, peace and harmony, not only does not threaten Western civilization or the rest of the world, but can bring mutual significant benefits. In total, one can agree that there is little evidence that Beijing is coordinating a single strategy to lure the developing world into overwhelming debt.

In official responses to OBOR criticism, Beijing tries to emphasize the non-forcing nature of its project and explain that BRI is not a product of its geopolitical or hegemonic ambitions and aspirations for world domination (Tritto, Camba, 2019). There are opinions that China's strategic task probably is not to support or intervene in other countries' economies in its own interests, but to obtain benefits primarily in the field of freight transportation, mining and in the development of new technologies. Actually, many states, especially in Central Europe, welcome Beijing's help and support. They are expressed in Chinese investment paving the way, expanding trade and interaction between neighboring countries who have insufficient funds for independent development, as well as offering promotional services for their products and so on (Gostev, 2019).

Perhaps a cause of concern and doubt regarding BRI is that the difficult business and political climate that exists in many developing countries makes it difficult to carry out the necessary comprehensive analysis, and even with the most careful preparation, the success of any BRI project cannot be fully guaranteed. In order to avoid negative consequences, China calls on countries that cannot bear the debt burden of large infrastructure projects not 
to accept them, and urges Chinese companies in advance to commit themselves to undertake appropriate risk and business viability studies so that recipient countries can pay off their debts (Feng, Gabuev, Haenle, Bin, Trenin, 2002). And in spite of accusations about Chinese debt traps, in which many countries find themselves, although without its coercion, Beijing continues to support many countries, investing more money in them than receiving benefits (Gostev, 2019).

It is noteworthy that during the 2019 Chinese B\&R Forum in Beijing, which brought together 37 world leaders and delegates from 150 countries and 90 international organizations, Xi Jinping demonstrated his responsiveness to the criticism of BRI and the challenges that OBOR countries faced. He promised to pay more attention to the debt sustainability, to focus on the development of the environment, to expand access to Chinese markets and to strengthen the protection of intellectual property (Huong, 2019).

\section{Internal challenges and criticism within China regarding the BRI projects}

In addition to external risks affecting the implementation of BRI, there are also internal risks and problems that may impede or undermine the Chinese initiative. And really, there are no guarantees that the BRI expects an easy victory, since at the moment China itself is still a developing country, facing enormous political, social and economic problems throughout the world.

However, from the very beginning of the proclamation of the initiative, there is criticism regarding the organizational nature of the NSR, since the largest project of global restructuring of the entire economic, and then, perhaps, of the political world is not represented in the organizational structure, but is called simply a movement (Gostev, 2019). There is a similar view that despite its ambitious intentions, issued in March 2015 by three ministries: the Ministry of Foreign Affairs, the National Development and Reform Commission and the Ministry of Commerce, the Action Plan for BRI more resembles a far-reaching statement of ambition without clear goals and guidelines. With a large and abstract wish list, without a coherent plan, different ministries can move in different directions, and the funding available to them, unlike headings, can be increased. And while Beijing emphasizes that BRI will follow market principles, as many government agencies and companies struggle for a piece of the pie, the risk of inefficient investments is high (Meidan, Patey, 2016).

Because of the struggle and competition for domestic resources between different regions and the weak interaction between them, there is almost no synergy between the governments of the provinces of Gansu, Qinghai and Xinjiang, which, with their common borders, geographical and cultural advantages, should focus on cooperation with Central Asia and Western Asia. Xenophobia and conservatism are very serious in many parts of China, and the government needs to improve regional integration. Another internal problem is ethnic tensions in Xinjiang and Tibet, where demands for greater autonomy and tension in relations with the central government led to outbreaks of violence against civilians and property. The separatist movements caused by ethnic conflicts attract terrorist activity in China, as well as in neighboring countries along the B\&R (Qingzhen, 2017).

It is believed that many Chinese companies, that have called themselves part of OBOR and export their business abroad for support and preferential access from the Chinese government, have a dubious reputation. With the growing number of Chinese enterprises expanding their activities in countries along the trade routes, some of them do more harm to the image of China than promote OBOR. And not all leading Chinese companies can serve OBOR, as they are limited by traditions, culture and language barriers (Qingzhen, 2017).

But most of all there are complaints that the country has too quickly stepped over and expanded the B\&R initiative, paying great attention to quick results, ignoring domestic problems in favor of development abroad and business opportunities (Feng, Gabuev, Haenle, Bin, Trenin, 2002). Some commentators have been critical of "excessive foreign aid" (Kondapalli, 2019). Prof. Xu Zhangrun of Tsinghua University wrote in his article "Imminent Fears, Immediate Hopes - A Beijing Jeremiad," that the average Chinese is often offended by the fact that the state disperses large sums of money through international assistance with little or no benefit (Xu, 2018).

This idea has been extended by Qingzhen (2017), suggesting that the Chinese will actually ask who pays the bills, since most countries in the developing world, where China is keen to spend money building ports, railroads and other projects, are low-income countries and slow profits. And if China subsidizes development projects in these countries, why the government does not do it in China, since the high economic boom in China in the late 1980 s - early 2000s led to huge inequalities, and many provinces still live below the poverty line. Social unrest and protests in inland China have become more frequent, and their discontent will be exacerbated if the Chinese do not see that they benefit or even lose in these foreign projects (Qingzhen, 2017).

\section{Conclusion}

As a result of this study, we can conclude that, despite the criticism and fears associated with the initiative of China, none of the "critics" who oppose BRI, including Westerners, does not mean a complete withdrawal from the project. Of course, one cannot exclude the possibility of leaving some BRI participants who are unhappy with Beijing, but so far there are no such countries. And the West, at least at this stage, will find it difficult to argue with the attractiveness of the Xi Jinping project. As for China, it should be said that under the "soft" scenario of 
development of events, Beijing will agree to make some cosmetic and even real changes to contracts and agreements to continue the project.

Although China is accused of setting a debt trap to seize control of strategic assets in the participating countries, especially in emerging economies with disabilities, fears that the Chinese government deliberately preys on countries in need of loans, in most cases unfounded. On the contrary, most BRI infrastructure projects are usually not commercially viable due to poor sovereign credit ratings of the borrowing countries, so China itself can accumulate debts in financing unproductive projects. And inefficient investments due to debts, as the main obstacles to China's growth and long-term stability, can threaten the country's economic growth and prosperity and lead to social and even political instability.

For their part, host countries can certainly take advantage of the opportunities provided by BRI, but if projects involving financial or economic problems are carried out mainly due to the availability of money, this can actually drive them into debt trap and impede economic development. Therefore, the participating countries should consider investment projects from a strategic point of view, guaranteeing public interest and taking into account development priorities. Both China and recipient countries should be interested in the commercial and economic viability of projects. And for the long-term development of BRI, Beijing and the governments of partner countries should be aware of all the risks and challenges and take measures to increase social, political, economic, security and environmental responsibility in the process of implementing BRI.

REFERENCES:

Алиев, Н. (2019)

Арутюнян, А. А. (2016)

Гостев, Ал. (2019)

Губин, А. (2009)

Гузенкова, Т.С., М.В. Карпов (2013) Глобализация по-китайски, или Китай в странах СНГ и Балтии. Страны СНГ и

ИАЦ МГУ (2019) Балтии в глобальной политике Китая. // Российский Институт Стратегических Исследований. - Москва: с. 5 - 22. (Guzenkova, T.S., M.V. Karpov. Globalization in Chinese, or China in the CIS and Baltic Countries. CIS and Baltic Countries in China's Global Politics. // Rossiyskiy Institut Strategicheskikh Issledovaniy (RISI). - Moskva: s. 5 - 22.)

Китай покупает политическую лояльность Армении? Media.Az беседует с востоковедом Алексеем Масловым. // Media.az, 08.04.2019. (10.04.2019) $<$ https://media.az/politics/1067730263/kitay-pokupaet-politicheskuyu-loyalnostarmenii-mediaaz-beseduet-s-vostokovedom-alekseemmaslovym/?fbclid=IwAR1 vXYuKpxnPvef0GEnkmwDpr5wU_3uzknHTDHzvXLE VIdqryzxxesJhxsU> (Aliyev, N. Is China Buying Armenia's Political Loyalty? Media.Az Talks with Orientalist Alexei Maslov. // Media.az, 08.04.2019. Date of access: 10.04.2019. Available at:

$<$ https://media.az/politics/1067730263/kitay-pokupaet-politicheskuyu-loyalnostarmenii-mediaaz-beseduet-s-vostokovedom-alekseemmaslovym/?fbclid=IwAR1 vXYuKpxnPvef0GEnkmwDpr5wU_3uzknHTDHzvXLE VIdqryzxxesJhxsU>)

Китайская инициатива экономического пояса Шелкового пути. - В: Материалы І международной конференции "Конфуцианские чтения" в РАУ. - Ереван.: Издво РАУ, с. $31-47$.

(Harutyunyan, A.A. Chinese Initiative of Economic Belt of the Silk Road. -V: Materialy I mezhdunarodnoy konferentsii "Konfutsianskiye chteniya" v RAU. Yerevan: Izd-vo RAU, s. $31-47$.)

Путин примеряет "Пояс". Чего ждать от визита президента России в Китай. // Радио Свобода, 26.04.2019. (26.04.2019) $<$ https://www.svoboda.org/a/29903688.html?fbclid= IwAR0nGMGZYSWkAw7r57e1ZNsaDXTick-kzDNqrijLCWPHK-

dx7a7eyov7XDw> (Gostev, Al. Putin Tries on "Belt". What to Expect from the Visit of the President of Russia to China. // Radio Svoboda, 26.04.2019. Date of access: 26.04.2019. Available at: $<\mathrm{https} / / \mathrm{www}$. svoboda.org/a/29903688.html?fbclid= IwAR0nGMGZYSWkAw7r57e1ZNsaDXTick-kzDNqrijLCWPHKdx7a7eyov7XDw>)

Рост напряжённости между США и КНР грозит нарушить работу механизма АСЕАН. // Российский институт стратегических исследований (РИСИ), 11.06.19. (11.06.19) <https://riss.ru/profile/gubin/9> (Gubin, A. Growing Tensions between the United States and China Threaten to Disrupt the Operation of the ASEAN Mechanism. // Rossiyskiy institut strategicheskikh issledovaniy (RISI), 11.06.19. Date of access: 11.06.19. Available at: $<$ https://riss.ru/profile/gubin/9>)

Кыргызстан попал в топ-5 главных должников Китая. Половина кредитов засекречена. // Информационно-аналитический Центр (ИАЦ) МГУ, 10.07.2019. (10.07.2019) <https://ia-centr.ru/publications/kyrgyzstan-popal-v-top-5-glavnykhdolzhnikov-kitaya-polovina-kreditov-

zasekrechena/?fbclid=IwAR2bFXuy3kTXPvsMIRBsU4JL0d4D96QPXhqcGjUlZD y0jIbnbDStajz0D5Q/> (Kyrgyzstan is in the Top 5 Main Debtors of China. Half 
Иванов, Р. (2018)

Комраков, А. (2019)

Легран, Ф. (2019)

Молдашев, К. (2019)

Хубиев, Р. (2019)

Abonyi, G. (2009)

Akpaninyie, M. (2019)

Almeida, M. (2018)

Bai, G. (2013)

Bart, G. (2018)

Bermingham, F. (2019)

Brautigam, D. (2019)
Credits are Classified. // Informatsionno-analiticheskiy Tsentr (IATS) MGU, 10.07.2019. Date of access: 10.07.2019. Available at: $<$ https://iacentr.ru/publications/kyrgyzstan-popal-v-top-5-glavnykh-dolzhnikov-kitayapolovina-kreditov-

zasekrechena/?fbclid=IwAR2bFXuy3kTXPvsMIRBsU4JL0d4D96QPXhqcGjUIZD y0jIbnbDStajz0D5Q/>)

5 проблем проекта «Один пояс - один путь». // 365 Info, 22.09.2018. (24.09.2018) <https://365info.kz/2018/09/5-problem-proekta-odin-poyas-odin-put $>$ (Ivanov, R. 5 Problems of the Project “One Belt - One Road". // 365 Info, 22.09.2018. Date of access: 24.09.2018. Available at: $<$ https://365info.kz/2018/09/5-problemproekta-odin-poyas-odin-put>)

Шелковый путь усыпан шипами. // Независимая газета, 22.04.2019. (25.04.2019) <http://www.ng.ru/economics/2019-0422/4_7563_silkway.html?fbclid=IwAR3k0fTlogQIcoqVNEx40hnN4B86gbTEZeT

WIxQPgb8rcwQpuD-8-EYicYc> (Komrakov A. The Silk Road is Studded with Spikes. // Nezavisimaya gazeta, 22.04.2019. Date of access: 25.04.2019. Available at: <http://www.ng.ru/economics/2019-04-

22/4 7563 silkway.html?fbclid=IwAR3k0fTlogQIcoqVNEx40hnN4B86gbTEZeT WIxQPgb8rcwQpuD-8-EYicYc $>$ )

Китайская головоломка для Евросоюза. // IPG-Международная политика и общество, 19.04.2019. (19.04.2019) <https://www.ipgjournal.io/regiony/evropa/statja/show/kitaiskaja-golovolomka-dlja-evrosojuza-777/> (Legran, F. Chinese Puzzle for the European Union. // IPG-Mezhdunarodnaya politika $i$ obshchestvo, 19.04.2019. Date of access: 19.04.2019. Available at: <https://www.ipg-journal.io/regiony/evropa/statja/show/kitaiskaja-golovolomkadlja-evrosojuza-777/>)

Риски в реализации инициативы «Один пояс, один путь» в Центральной Азии. // Аналитика, 11.01.2019. (11.01.2019) <https://analytics.cabar.asia/ru/riski-vrealizatsii-initsiativy-odin-poyas-odin-put-v-tsentralnoj-

azii/?fbclid=IwAR2bcHNzllt_SiFwe2Zu2bTu0tdtXqYAVlQsjc58cDKypEXcGV5jri $\mathrm{NxcPc}>$ (Moldashev, K. Risks in the Implementation of the "One Belt, One Road" Initiative in Central Asia. // Analitika, 11.01.2019. c. 1-11. Date of access: 11.01.2019. Available at: $<$ https://analytics.cabar.asia/ru/riski-v-realizatsiiinitsiativy-odin-poyas-odin-put-v-tsentralnoj-

azii/?fbclid=IwAR2bcHNzllt_SiFwe2Zu2bTu0tdtXqYAV1Qsjc58cDKypEXcGV5jri $\mathrm{NxcPc}>$ )

США и Шелковый путь: Пекин и Москва успешно держат оборону. // ИА REGNUM, 19.05.2019. (19.05.2019) <https://regnum.ru/news/2630957.html> (Khubiev, R. US and Silk Road: Beijing and Moscow Successfully Hold the Defense. // IA REGNUM, 19.05.2019. Date of access: 19.05.2019. Available at: $<$ https://regnum.ru/news/2630957.html >)

With Belt and Road Projects, Consider the China Risk. // Asia Global Online, 11.06.2019. Date of access: 11.06.2019. Available at: $<$ https://www.asiaglobalonline.hku.hk/with-belt-and-road-projects-consider-thechina-risk/?fbclid=IwAR2DffhfPA7LBW5myQ8sHcoOyFYtMWg43FlCs8bteRQG_HufeUVFbNSXNo>

China's 'Debt Diplomacy' Is a Misnomer. Call It 'Crony Diplomacy'. // The Diplomat, 12.03.2019. Date of access: 12.03.2019. Available at:

$<$ https://thediplomat.com/2019/03/chinas-debt-diplomacy-is-a-misnomer-call-itcrony-diplomacy/>

China's 'Marshall Plan' for the Arab world. // Arab News, 14.07.2018. Date of access: 14.07.2018. Available at: <http://www.arabnews.com/node/1338856>

From Maritime Asia to Continental Asia: China's Responses to the Challenge of the Trans-Pacific Partnership. - In: Stanford University. Stanford (California). October, p. $1-22$.

Europe's Connectivity Strategy and the Challenge of China: Rivalry, Reciprocity, or Both? // The Finnish Institute of International Affairs (FIIA), 05.12.2018. Date of access: 05.12.2018. Available at: $<$ https://www.fiia.fi/sv/publikation/europesconnectivity-strategy-and-the-challenge-of-china?read $>$

China Throws Trade War Tariff Exclusion Lifelines That It Thought It Would Never Need. // South China Morning Post, 14.05.2019. Date of access: 14.05.2019. Available at: <https://www.scmp.com/economy/chinaeconomy/article/3010197/china-throws-trade-war-tariff-exclusion-lifelines-itthought>

Is China the World's Loan Shark? // The New York Times, 26.04.2019. Date of access: 26.04.2019. Available at: <https://www.nytimes.com/2019/04/26/opinion/china-belt- 
Bremmer, I. (2014)

Brown, K. (2018)

Brugier, C. (2014)

Bujak, A., Z. Śliwa (2016)

Cameron, F. (2018)

Chan, J. (2018)

Chellaney, B. (2016)

Cheney, C. (2019)

China and US Focus (2015)

Degang, S. (2015)

Dingding, Ch., H. Junyang (2019)

Domínguez, G., J. Juan, (2015)

Dorsey, J. (2018)

Dubow, Ph. (2017)

Elbir, H. Ç. (2019)

Feng, Y., Al. Gabuev, P. Haenle, M. Bin, The Belt and Road Initiative: Views from Washington, Moscow, and Beijing. // D. Trenin, (2019)

Harutyunyan, Agh. (2016)

Harutyunyan, Agh. (2017a)

road-initiative.html?fbclid=IwAR1 U4C-

VW0j3J81WLYHH9YgvTfwOHf_hmfuN9MTioFierXRIo5nNvLpDuu8>

Rusia, Occidente y la incógnita de China. // El Pais, 18.08.2014. Date of access: 18.08.2014.

$<$ http://elpais.com/elpais/2014/08/14/opinion/1408013805_239077.html> (Bremmer $Y$., Russia, the West and the Mystery of China. // El' Pais, 18.08.2014. Date of access: 18.08.2014. Available

$<$ http://elpais.com/elpais/2014/08/14/opinion/1408013805_239077.html>)

The Belt and Road: Security Dimensions. // Springer, Asia Europe Journal. Vol. 16, Issue 3, September, p. $213-222$.

China's Way: The New Silk Road, Brief Issue. // European Union Institute for Security Studies, May, p. $1-4$

Global Aspects of Security Environment - the 'One Belt, One Road' Project. // Ekonomia i Prawo. Economics and Law. 15(4), p. 439 - 454.

$<\mathrm{https}$ ///www.researchgate.net/publication/313816677_Global_aspects_of_security_ environment_-_the_One_Belt_One_Road'_project>

Europe's Answer to China's Belt and Road. // The Diplomat, 19.09.2018. Date of access: 19.09.2018. Available at: $<$ https://thediplomat.com/2018/09/europesanswer-to-chinas-belt-and-road/>

Europe's Challenge to China. // The Diplomat, 26.10.2018. Date of access: 26.10.2018. Available at: <https://thediplomat.com/2018/10/europes-challenge-tochina/>

China's Dam Problem with Myanma. // The Strategist, 14.09.2016. Date of access: 13.07.2018. Available at: <https://www.aspistrategist.org.au/chinas-dam-problemmyanmar/>

China's Digital Silk Road Could Decide the US-China Competition. // The Diplomat, 17.07.2019. Date of access: 17.07.2019. Available at: $<$ https://thediplomat.com/2019/07/chinas-digital-silk-road-could-decide-the-uschina-

competition/?fbclid=IwAR13jWK4dwtxwtRtQOsxSzupa2qDY88hj72ga1pNaDyaH AFgEf7pq3hqUNY>

China's 'One Belt, One Road' Strategy is not another Marshall Plan. // China and US Focus, 16.03.2015. Date of access: 16.03.2015. Available at: <http://www.chinausfocus.com/finance-economy/china-advances-its-one-beltone-road-strategy/>

China's Soft Military Presence in the Middle East. // Middle East Institute, 11.03.2015. Date of access: 11.03.2015. Available at: $<$ https://www.mei.edu/publications/chinas-soft-military-presence-middle-east $>$ 3 Ways China Can Make the Belt and Road Initiative More Successful. // The Diplomat, 21.05.2019. Date of access: 21.05.2019. Available at: <https://thediplomat.com/2019/05/3-ways-china-can-make-the-belt-and-roadinitiative-more-

successful/?fbclid=IwAR21tOK7RPyWDo_Vh6wxPiJZTIYKDtbW6jJHXI1AA TDsTmTrm7VB0FZYKaA>

Soft Power - China's Expanding Role in the Middle East. // Deutsche Welle, 04.02.2015. Date of access: 04.02.2015. Available at: $<\mathrm{https}: / / \mathrm{www} . \mathrm{dw} . \mathrm{com} / \mathrm{en} / \mathrm{soft}-$ power-chinas-expanding-role-in-the-middle-east/a-18233271>

China Adds Security Component to Belt and Road Initiative. // LobeLog, 24.08.2018. Date of access: 24.08.2018. Available at: $<$ https://lobelog.com/china-adds-securitycomponent-to-belt-and-road-initiative/https://mail.google.com $/ \mathrm{mail} / \mathrm{u} / \mathrm{0} /$ sent/FMfcgxvxBPMSvbkbfpJxPpcCrpvmXqzq>

Is China's Belt and Road Initiative Increasing Crime and Terrorism? // The Diplomat, 07.11.2017. Date of access: 07.11.2017. Available at: $<$ https://thediplomat.com/2017/11/is-chinas-belt-and-road-initiative-increasingcrime-and-terrorism/>

The Charming Modern Silk Road Dazzles the EU. // Center for Eurasian Studies (AVIM). Analysis NO 12, April 29, p. 1 -6.

Carnegie-Tsinghua. Center for Global Policy, 08.04.2019. Date of access: 09.05.2019. Available at: <https://carnegietsinghua.org/2019/04/08/belt-and-roadinitiative-views-from-washington-moscow-and-beijing-pub-78774?sfns=mo $>$ Chinese Peaceful Rise and Development. The Theory of "China's Threat". - In: The Countries and Peoples of the Near and Middle East. - Yerevan: IOS NAS RA, p. 216 $-227$.

From China's Concept of Peaceful Rise to the Chinese Great Dream. Mauritius: LAP Lambert Academic Publishing, 84 p. 
Harutyunyan, Agh. (2017b)

Harutyunyan, A. A. (2017c)

Harutyunyan, Agh. (2018a)

Harutyunyan, Agh. (2018b)

Harutyunyan, Agh. (2018c)

Harutyunyan, Agh. (2018d)

Kaczmarski, M. (2016)

Kondapalli, S. (2019)

Kuronuma, Y. (2018)

Liu, H. (2017)

Maráczi, F. (2017)

Meidan, M., L. Patey, (2016)

Mokhtari, S. (2018)

Molavi, A. (2018)

National University of Singapore (2017)China's OBOR: Opportunities and Challenges, Lee Kuan Yew School of Public Policy. // National University of Singapore, 07.02.2017. Date of access: 07.02.2017. Available at: <https://lkyspp.nus.edu.sg/gia/article/china-s-obor-opportunities-andchallenges>

Panda, A. (2015)

Pars Today (2009)

Pei, M. (2019)

Qingzhen, Ch. (2017)

Chinese One Belt, One Road Initiative: Challenges and Opportunities. Mauritius: LAP Lambert Academic Publishing, 288 p.

Russia and China: On the Creation of "a Common Eurasian Economic Space". - B: Россия - Китай: История и Культура: Сборник статей и докладов участников $\mathrm{X}$ международной научно-практической конференции. - Казань: Издательство: Академии наук РТ, с. 18 - 26.

(Harutyunyan, A.A. Russia and China: On the Creation of "a Common Eurasian Economic Space". -V: Rossiya - Kitay: Istoriya i Kul'tura: Sbornik statey i dokladov uchastnikov X mezhdunarodnoy nauchno-prakticheskoy konferentsii. - Kazan': Izdatel'stvo: Akademii nauk RT, s. 18 - 26.)

Chinese Initiative "One Belt, One Road" and the Idea of "Community of Common Destiny". // Eastern Asian Studies. Vol.: 3. Yerevan: IOS NAS RA, p. 48 - 62.

Chinese Policy of Soft Power and Public Diplomacy. // The Countries and Peoples of the Near and Middle East. Vol. 31. - Yerevan: IOS NAS RA, p. 171 - 194.

Chinese One Belt, One Road and the European Countries. // Cultures and Societies of South, East and Southeast Asia: Traditionalism, Dynamics and Globalization. Vol. 4, Issue 2. Manas: Electronic Journal of the Centre for Eastern Languages and Cultures, Sofia University "St. Kliment Ohridski” (CELC), p. 1-45.

Chinese Initiative "One Belt, One Road" and the Idea of "Community of Common Destiny". // Eastern Asian Studies. Vol. 3. Yerevan: IOS NAS RA, p. 48 - 62.

'Silk Globalisation' China's Vision of International Order. // OSW Point of View. Centre for Eastern Studies. No 60, Ośrodek Studiów Wschodnich im. Marka Karpia, Warsaw, October, p. $1-28$.

China's Belt and Road Initiative: From Arctic to space, How China Plans to Expand its Global Footprints. // Financial Express, 24.04.2019. Date of access: 28.04.2019. Available at: $<$ https://www.financialexpress.com/defence/chinas-belt-and-roadinitiative-from-arctic-to-space-how-china-plans-to-expand-its-globalfootprints/1557484/>

India Offers Maldives $\$ 1$ bn in Loans to Help Repay China Debt. // Nikkei Asian Review, 28.11.2018. Date of access: 23.01.2019. Available at: $<$ https://asia.nikkei.com/Politics/International-Relations/India-offers-Maldives1bn-in-loans-to-help-repay-China-debt $>$

The Security Challenges of the "One Belt, One Road" Initiative and China's Choices. // CIRR. 23 (78), August, p. $129-147$.

Security Challenges of One Belt One Road Initiative. // The Belt \& Road Center. The Pallas Athéné Geopolitical Foundation (PAGEO) and the Pallas Athéné Domus Mentis Foundation (PADMA), 07.11.2017. Date of access: 01.01.2018. Available at: $<$ http://beltandroadcenter.org/2017/11/07/security-challenges-of-one-belt-oneroad-initiative/>

The Challenges Facing China's Belt and Road Initiative. // The Center for Security Studies (CSS). ETH Zurich, 29.03.2016. Date of access: 12.05.2019. Available at: $<$ http://www.css.ethz.ch/en/services/digital-library/articles/article.html/196072>

Mokhtari Somayeh, 'One Belt-One Road', Silk Road's New Challenges, Opportunities. // MEH News Agency, 10.07.2018. Date of access: 12.09.2018. Available at: $<$ https://en.mehrnews.com/news/135572/One-Belt-One-Road-SilkRoad-s-new-challenges-opportunities $>$

Enter the Dragon: China's Belt and Road Rising in The Middle East. // Hoover Institution or Stanford University. Issue 1819, 02.10.2018. Date of access: 02.10.2018. Available at: <https://www.hoover.org/research/enter-dragon-chinas-

China's Sri Lankan Port Ambitions Persist. // The Diplomat, 27.07.2015. Date of access: 26.09.2017. Available at: <http://thediplomat.com/2015/07/chinas-srilankan-port-ambitions-persist/>

Вызовы на пути реализации проекта "Один пояс, один путь". // Pars Today, 09.03.2019. (09.03.2019) <http://parstoday.com/ru/radio/programs-i99273> (Challenges on the Way to the Implementation of the Project "One Belt, One Road". // Pars Today, 09.03.2019. Date of access: 09.03.2019. Available at: $<\mathrm{http}: / /$ parstoday.com/ru/radio/programs-i99273>)

Will China Let Belt and Road Die Quietly? // Nikkei Asian Review, 15.02.2019. Date of access: 15.02.2019. Available at: $<$ https://asia.nikkei.com/Opinion/Will-China-letBelt-and-Road-die-quietly?sfns $=\mathrm{mo}>$

Three Domestic Challenges of China's One Belt, One Road Initiative. // Global Risk Insight, 19.06.2017. Date of access: 06.11.2017. Available 
Ramachandran, S. (2019)

Sharma, M. (2019)

Spivak, V. (2017)

Sputnik (2015)

Sputnik (2019)

Szczudlik-Tatar, J. (2013)

The Economist Intelligence Limited (2015)

The Hague Centre for Strategic StudiesThe Belt and Road Initiative Looks East. Political Implications of China's Economic (2018)

Trenin, D. (2019)

Trickett, N. (2017)

Tritto, A., A. Camba (2019)

VAAJU.COM (2018)

Vien, Th. (2015)

Xinhua. english.news.cn (2017)

Xu, Zh. (2018)

Wong, A. A., S. Jia (2017)

Zhang, H. (2015)

at: https://globalriskinsights.com/2017/06/three-domestic-challenges-chinas-onebelt-one-road-initiative/

The Standoff Over the Myitsone Dam Project in Myanmar: Advantage China. // China Brief. Vol. 19 Issue: 8, The Jamestown Foundation, April 24.

The World Shouldn't Save the Belt and Road. // Bloomberg, 02.05.2019. Date of access: $\quad 02.05 .2019$. Available at: $<$ https://www.bloomberg.com/opinion/articles/2019-05-01/western-capitalshouldn-t-help-build-china-s-belt-and-road?sfns=mo>

How Putin Plans to Cash in on the One Belt One Road Initiative. // Russia Beyond, 16.05.2017. Date of access: 16.05.2017. Available at: $<$ https://www.rbth.com/international/2017/05/16/putin-plans-one-belt-one-roadinitiative-763456>

Eurasian Heartland: Silk Road and EEU to Solidify Sino-Russian Relations. // Sputnik, 12.06.2015. Date of access: 12.06.2015. Available at: $<$ http://sputniknews.com/business/20150612/1023289572.html>

Balochistan Militants Issue Threat to Chinese President, Pakistan - Report. // Sputnik, 20.05.2019. Date of access: 20.05.2019. Available at: $<$ https://sputniknews.com/asia/201905201075152566-baloch-militants-threatencpec-china/?fbclid=IwAR1QrXHg3djI6h-

D1JsCEPQzPpkjgeqMsyzl8X6Z4xrysZAMEFwolA6bTbE>

China's New Silk Road Diplomacy. // The Polish Institute of International Affaires (PISMP). No. 34 (82), December, p. $1-8$.

UnitProspects and Challenges on China's 'One Belt, One Road': A Risk Assessment Report. // The Economist Intelligence Unit Limited, p. 1 - 23.

Forays in the Caribbean and the South Pacific. // The Hague Centre for Strategic Studies. HCSS Global Trends, p. $1-97$.

China, Russia and the United States Contest a New World Order. // The Carnegie Moscow Center, 07.05.2019. Date of access: 07.05.2019. Available at: $<$ https://carnegie.ru/2019/05/07/china-russia-and-united-states-contest-new-

world-order-pub-

79078? fbclid=IwAR1ZvzOiPPHjX5VjaZGAnOVZloRAu1XQM09A3MK81vbeEX R3vhYSmzKsWPg>

The Gordian Rail Tie: Russia's Mythic Belt and Road Cooperation. // The Diplomat, 20.10.2017. Date of access: 20.10.2017. Available at: $<$ https://thediplomat.com/2017/10/the-gordian-rail-tie-russias-mythic-belt-androad-cooperation/>

The Belt and Road: The Good, the Bad, and the Mixed. // The Diplomat, 15.04.2019. Date of access: 15.04.2019. Available at: $<$ https://thediplomat.com/2019/04/the-beltand-road-the-good-the-bad-and-the-mixed/>

To Counteract "Made in China 2025"! US Plans to Limit China's Investment in Aviation, Robots Companies. // VAAJU.COM, 25.06.2018. Date of access: 25.06.2018. Available at: $<$ https://vaaju.com/taiwaneng/to-counteract-made-inchina-2025-us-plans-to-limit-chinas-investment-in-aviation-robots-companiesettoday-international-ettoday-news-cloud/>

The Grand Design of China's New Trade Routes. // Stratfor, 24.06.2015. Date of access: 24.06.2015. Available at: $<$ https://www.stratfor.com/analysis/granddesign-chinas-new-trade-routes>

Spotlight: China, Europe Expects Deeper Cooperation, Brighter Future. // Xinhua. english.news.cn, 02.04.2017. Date of access: 15.09.2018. Available at: <http://news.xinhuanet.com/english/2017-04/02/c 36178254.htm>

Imminent Fears, Immediate Hopes - A Beijing Jeremiad. // China Heritage. The Wairarapa Academy for New Sinology, July 2018. Date of access: 12.04.2018. Available at: <http://chinaheritage.net/journal/imminent-fears-immediate-hopes-abeijing-jeremiad/>

Belt \& Road: Opportunity \& Risk. // Baker \& McKenzie International. p. $1-26$.

'Belt and Road,' AIIB to Boost China-EU Relations. // China.org.cn, 14.05.2015. Date of access: 14.05.2015. Available at: $<\mathrm{http}$ ://www.china.org.cn/opinion/201505/14/content 35570562.htm> 